\title{
Study on safety risk warning index for highway construction project
}

\author{
Jianhua PENG \\ China Academy of Transportation Sciences, Beijing, China
}

\begin{abstract}
KEYWORD: Highway construction project; Safety risk; Warning index; Warning situation ABSTRACT: Establishment of safety risk warning system of highway construction project can prevent accident effectively. Four warning situations have been ascertained, such as low safety capacity of highway construction project, reduction of safety capacity of highway construction project, existence of major safety defect in highway construction project, and existence of repetitive safety defect in highway construction project. Based on safety risk assessment of highway construction project, warning indexes toward four warning situations have been put forward respectively, providing technical support to the establishment of safety risk warning system of highway construction project.
\end{abstract}

\section{INTRODUCTION}

Because of the heavy highway construction tasks and the high risk of the project itself, China's highway construction project safety production situation is grim, the task is very arduous. Establishment of highway construction project safety risk early warning system, forecasting the possible situation of the highway construction project timely and accurately, and taking corresponding measures, will be able to avoid the occurrence of accidents effectively. In this paper, combined with the highway construction project safety risk assessment, the highway construction project safety risk early warning indicators are studied, providing technical support for the establishment of highway construction project safety risk early warning system.

\section{SAFETY RISK ASSESSMENT OF HIGHWAY CONSTRUCTION PROJECT}

The key scientific basis for the safety risk early warning of the highway construction project is to evaluate the safety production level of the highway construction project accurately and beforehand. From the safety system elements of highway construction project, highway construction project safety risk assessment should accord to the inherent $\operatorname{risk}(\mathrm{G})$, safety management level of construction unit(M1), safety management level of project owner(M2), and safety management level of supervision unit(M3). These factors are refined to determine the evaluation index and criteria. Using the fuzzy comprehensive evaluation method, the safety level of highway construction project can be evaluated. The value of evaluation index can use centesimal system [100,0]. Safety grade division for highway construction project can adopt the experience mode (see Table 1).

Table 1. Safety grade division for highway construction project

\begin{tabular}{lllll}
\hline Safety grade & I & II & III & IV \\
\hline Level & Safe & Relatively safe & $\begin{array}{l}\text { Relatively } \\
\text { gerous }\end{array}$ & dan- \\
\hline Values range & {$[100,90]$} & $(90,75]$ & $(75,60]$ & $(60,0]$ \\
\hline
\end{tabular}

\section{THE DETERMINATION OF WARNING SITUATION}

According to the characteristics of highway construction project safety production, the following four kinds of monitoring and forecasting situation are identified. 


\section{Low safety capacity of highway construction project}

Highway construction project safety capacity is the basic attribute of highway construction project, revealing its ability to ensure safety and to resist risk accidents. When the highway construction project safety capacity is insufficient, the risk of potential accidents is greater.

\section{Reduction of safety capacity of highway construction project}

Along with the progress of highway construction project and the change of construction task, the safety capacity of highway construction project is constantly changing. When the safety capacity of highway construction projects is weakened, the risk of potential accidents is increasing.

\section{Existence of major safety defect in highway construction project}

Safety production of highway construction project is a complex and multi factor system. When safety management level of construction unit, project owner, or supervision unit is very vulnerable, it can be regarded as a major safety defect in highway construction project. Its impact can be extended to the overall safety of highway construction project.

\section{Existence of repetitive safety defect in highway construction project}

If major safety defect of the highway construction project has not been corrected timely, it can be regarded as a repetitive safety defect in highway construction project. The influence of defect on the safety production of highway construction project will be further deepened, and the impact may be multiple and malignant.

\section{EARLY WARNING INDEX}

According to the above four kinds of warning situation, the following warning indicators are identified.

\section{Safety level of highway construction project(S)}

The safety level of highway construction project is the direct expression of safe capacity of highway construction project. When the value of safety level is lower than a certain critical value(L), it can be used as a warning sign of the lack of safety capacity of highway construction project. Safety level of highway construction project is also the comprehensive safety risk assessment index of highway construction project.

According to safety grade division for highway construction project based on Table 1, when $\mathrm{S}$ value is at $[100,75]$, highway construction project safety production is in a controlled state, don't issue a warning(or warning degree is no warning). when $S$ value is at $(75,60]$, safety capacity of highway construction project is insufficient, warning degree is medium warning, and $\mathrm{L}$ is 75 . when $\mathrm{S}$ value is at $(60,0]$, safety capacity of highway construction project is severely insufficient, warning degree is severe warning, and $\mathrm{L}$ is 60 . The division criteria of safety level warning line for highway construction project is shown in Table 2 .

Table 2. Division criteria of safety level warning line for highway construction project

\begin{tabular}{|c|c|c|c|}
\hline Warning degree & No warning & Medium warning & $\begin{array}{l}\text { Severe } \\
\text { warning }\end{array}$ \\
\hline $\mathrm{S}$ & {$[100,75]$} & $(75,60]$ & $(60,0]$ \\
\hline $\begin{array}{l}\text { Description of warn- } \\
\text { ing situation }\end{array}$ & $\begin{array}{l}\text { Highway construction } \\
\text { project safety produc- } \\
\text { tion is in a controlled } \\
\text { state }\end{array}$ & $\begin{array}{l}\text { Safety capacity of } \\
\text { highway construction } \\
\text { project is insufficient, } \\
\text { accident risk is relative } \\
\text { higher }\end{array}$ & $\begin{array}{l}\text { Safety capacity of } \\
\text { highway construction } \\
\text { project is severely in- } \\
\text { sufficient, accident risk } \\
\text { is higher }\end{array}$ \\
\hline Control method & $\begin{array}{l}\text { Daily management and } \\
\text { normal monitoring }\end{array}$ & $\begin{array}{l}\text { Measures must be tak- } \\
\text { en to improve safety } \\
\text { capacity, reduce risk, } \\
\text { and strengthen monitor- } \\
\text { ing }\end{array}$ & $\begin{array}{l}\text { Must attach great im- } \\
\text { portance, and take } \\
\text { measures to improve } \\
\text { safety capacity imme- } \\
\text { diately }\end{array}$ \\
\hline
\end{tabular}




\section{Variation range of safety level of highway construction $\operatorname{project}(\Delta S)$}

The safety level of highway construction project is an inherent attribute value of highway construction project. Along with the progress of the project, the safety level of highway construction project is also in constant change. When the highway construction project begin its first safety risk assessment, it will get the initial value of safety level of highway construction $\operatorname{project}\left(\mathrm{S}_{0}\right)$. After each complete monitoring and safety risk assessment, there will be a reflection of the current stage of highway construction project safety level $\left(\mathrm{S}_{\mathrm{i}}\right)$. The difference between two adjacent safety risk assessment of highway construction project(See Equation 1) is variation range of safety level of highway construction $\operatorname{project}(\triangle S)$.

$$
\Delta S=S_{i}-S_{i-1}
$$

where $S_{i}=$ safety value of highway construction project in the $\mathrm{i}$-th safety risk assessment; $S_{\mathrm{i}-1}=$ safety value of highway construction project in the (i-1)-th safety risk assessment.

When variation range of safety level of highway con-struction $\operatorname{project}(\triangle S)$ is positive, it means that the highway construction project safety capacity has been strengthened. When variation range of safety level of highway construction $\operatorname{project}(\triangle S)$ is negative, it means that the highway construction project safety capacity has been weakened. At this time, even if the highway construction project safety production is in a controlled state, it may be out of control in future, if the corresponding measures are not implemented in time. Therefore, it is necessary to carry out early warning.

According to safety grade division for highway construction project based on Table 1 , when the $\triangle S$ value is in $[0,100)$, it means highway construction project safety capacity is not weakened, don't issue a warning(or warning degree is no warning). When the $\triangle S$ value is in [-10,0), it means highway construction project safety capacity is weakened, warning degree is slight warning, and L is zero. When the $\triangle S$ value is in $[-25,-10)$, it means highway construction project safety capacity is weakened significantly, warning degree is medium warning, and L is -10. When the $\triangle S$ value is in ($100,-25)$, it means highway construction project safety capacity is weakened sharply, warning degree is severe warning, and $\mathrm{L}$ is -25 . The division criteria of the variation range of safety level of highway construction project is shown in Table 3.

Table 3. Division criteria of the variation range of safety level of highway construction project

\begin{tabular}{|c|c|c|c|c|}
\hline Warning degree & $\begin{array}{l}\text { No } \\
\text { warning }\end{array}$ & $\begin{array}{l}\text { Slight } \\
\text { warning }\end{array}$ & Medium warning & $\begin{array}{l}\text { Severe } \\
\text { warning }\end{array}$ \\
\hline$\triangle S$ & {$[0,100)$} & {$[-10,0)$} & {$[-25,-10)$} & $(-100,-25)$ \\
\hline $\begin{array}{l}\text { Description of } \\
\text { warning situa- } \\
\text { tion }\end{array}$ & $\begin{array}{l}\text { Highway con- } \\
\text { struction project } \\
\text { safety capacity is } \\
\text { maintained or } \\
\text { strengthened }\end{array}$ & $\begin{array}{l}\text { Highway con- } \\
\text { struction project } \\
\text { safety capacity is } \\
\text { weakened }\end{array}$ & $\begin{array}{l}\text { Highway con- } \\
\text { struction project } \\
\text { safety capacity is } \\
\text { weakened signifi- } \\
\text { cantly }\end{array}$ & $\begin{array}{l}\text { Highway con- } \\
\text { struction project } \\
\text { safety capacity is } \\
\text { weakened sharply }\end{array}$ \\
\hline Control method & $\begin{array}{l}\text { Daily manage- } \\
\text { ment and normal } \\
\text { monitoring }\end{array}$ & $\begin{array}{l}\text { Pay attention, and } \\
\text { strengthen } \\
\text { monitoring }\end{array}$ & $\begin{array}{l}\text { Pay attention, take } \\
\text { measures to im- } \\
\text { prove safety ca- } \\
\text { pacity, and streng- } \\
\text { then monitoring }\end{array}$ & $\begin{array}{l}\text { Must Attach great } \\
\text { imortance, and } \\
\text { take measures to } \\
\text { improve safety } \\
\text { capacity imme- } \\
\text { diately }\end{array}$ \\
\hline
\end{tabular}

\section{Major safety defect in highway construction project}

In the safety risk assessment of highway construction project, if safety management level of construction unit(M1), safety management level of project owner(M2), or safety management level of supervision unit(M3) is in (75,0], it means major safety defect in highway construction project is existed. At this point, even if the highway construction project safety production as a whole is in a 
controlled state, it is most likely out of control in future, if the corresponding measures are not implemented in time. Therefore, it is necessary to carry out early warning.

When all of M1, M2 and M3 are in [100,75], there is no major safety defect in highway construction project, don't issue a warning(or warning degree is no warning). When M1, M2 or M3 is in $(75,60]$, there is a major safety defect in highway construction project, warning degree is medium warning, and $\mathrm{L}$ is 75 . When M1, M2 or M3 is in $(60,0]$, there is an extraordinarily major safety defect in highway construction project, warning degree is severe warning, and $\mathrm{L}$ is 60 . The division criteria of major safety defect in highway construction project is shown in Table 4.

Table 4. Division criteria of major safety defect in highway construction project

\begin{tabular}{|c|c|c|c|}
\hline Warning degree & $\begin{array}{l}\text { No } \\
\text { warning }\end{array}$ & Medium warning & $\begin{array}{l}\text { Severe } \\
\text { warning }\end{array}$ \\
\hline $\mathrm{M} 1, \mathrm{M} 2$ or $\mathrm{M} 3$ & {$[100,75]$} & $(75,60]$ & $(60,0]$ \\
\hline $\begin{array}{l}\text { Description of warn- } \\
\text { ing situation }\end{array}$ & $\begin{array}{l}\text { No major safety defect } \\
\text { in highway construc- } \\
\text { tion project }\end{array}$ & $\begin{array}{l}\text { Major safety defect in } \\
\text { highway construction } \\
\text { project }\end{array}$ & $\begin{array}{l}\text { Extraordinarily major } \\
\text { safety defect in highway } \\
\text { construction project }\end{array}$ \\
\hline Control method & $\begin{array}{l}\text { Daily management and } \\
\text { normal monitoring }\end{array}$ & $\begin{array}{l}\text { Pay attention, take } \\
\text { measures to eliminate } \\
\text { major safety defect, } \\
\text { and strengthen moni- } \\
\text { toring }\end{array}$ & $\begin{array}{l}\text { Must attach great impor- } \\
\text { tance, and take meas- } \\
\text { ures to eliminate extra- } \\
\text { ordinarily major safety } \\
\text { defect immediately }\end{array}$ \\
\hline
\end{tabular}

Among them: M1 corresponds to the major defect existing in the highway construction project construction unit, M2 corresponds to the major defect existing in the highway construction project owner, M3 corresponds to the major defect existing in the highway construction project supervision unit.

\section{Repetitive safety defect in highway construction project}

In the safety risk assessment of highway construction project, if safety management level of construction unit(M1), safety management level of project owner(M2), or safety management level of supervision unit(M3) is in $(75,0]$ no less than twice in succession, it means repetitive safety defect in highway construction project is existed. At this point, even if the highway construction project safety production as a whole is in a controlled state, the safety production of highway construction project has not attracted enough attention and continuous improved, it is most likely out of control in future, if the corresponding measures are not implemented in time. Therefore, it is necessary to carry out early warning.

The division criteria of repetitive safety defect in highway construction project is shown in Table 5 .

Table 5. Division criteria of repetitive safety defect in highway construction project

\begin{tabular}{lll}
\hline Warning degree & No warning & Severe warning \\
\hline M1, M2 or M3 & Be in $(75,0]$ less than twice in & $\begin{array}{l}\text { Be in }(75,0] \text { no less than twice in } \\
\text { succession }\end{array}$ \\
$\begin{array}{l}\text { Description of warning situa- } \\
\text { tion }\end{array}$ & $\begin{array}{l}\text { No repetitive safety defect in } \\
\text { highway construction project } \\
\text { Repetitive safety defect in high- } \\
\text { way construction project }\end{array}$ \\
Control method & $\begin{array}{l}\text { Dust management and normal } \\
\text { monitoring }\end{array}$ & $\begin{array}{l}\text { Muke measures to eliminate repeti- } \\
\text { take } \\
\text { tive safety defect immediately }\end{array}$ \\
\hline
\end{tabular}

Among them: M1 corresponds to the repetitive defect existing in the highway construction project construction unit, M2 corresponds to the repetitive defect existing in the highway construction project owner, M3 corresponds to the repetitive defect existing in the highway construction project supervision unit. 


\section{CONCLUSIONS}

(1) Four warning situations have been ascertained, such as low safety capacity of highway construction project, reduction of safety capacity of highway construction project, existence of major safety defect in highway construction project, and existence of repetitive safety defect in highway construction project.

(2) According to four kinds of warning situation, the corresponding early warning indexes are put forward, including safety level of highway construction project(S), variation range of safety level of highway construction project $(\triangle S)$, major safety defect in highway construction project, and repetitive safety defect in highway construction project.

(3) The division criteria of the four warning indexes are put forward respectively. According to different type and level of warning situation, the corresponding control method is put forward.

\section{REFERENCES}

1) China Academy of Transportation Sciences(CATS). 2007. Research on key technologies of highway and waterway engineering. Beijing: CATS.

2) China Academy of Transportation Sciences(CATS). 2010. Early warning procedure for safety production of highway and waterway construction project. Beijing: CATS.

3) China Academy of Transportation Sciences(CATS). 2010. Research on safety evaluation technology of highway and waterway construction project. Beijing: CATS.

4) GAO, Wei. 2007. The application of safety control fore-warning and auxiliary decision technology in the high-risk situation. Journal of Safety Science and Technology 3(2):103-106.

5) LIN, Cheng. 2006. Application of pre-alarm safety management technique in construction. Journal of Construction Technology35(5):31-34.

6) ZHANG, Xingkai. 2005. Brief analysis on crisis warning for work safety. Journal of Safety Science and Technology 1(1):36-40. 